\title{
Immune response of channel catfish to lipopolysaccharide and whole cell Edwardsiella ictaluri vaccines
}

\author{
M. O. Saeed* \& J. A. Plumb** \\ Department of Fisheries and Allied Aquacultures, Alabama Agricultural Experiment Station, Auburn University, \\ Alabama 36849, USA
}

\begin{abstract}
The efficacy of Edwardsiella ictaluri lipopolysaccharide (LPS) and of formalin-killed E. ictaluni whole cell bacterins was investigated in channel catfish Ictalurus punctatus. Vaccine efficacy was measured in terms of serum agglutinin production and enhanced immunity to experimental challenge with the pathogen. Multiple injections of LPS in Freund's complete adjuvant (FCA) produced higher antibody titers (1391) than multiple injections of LPS in saline (131), and protection conferred by the former technique was also greater 3.3 vs $36.7 \%$ mortality while unvaccinated controls suffered $70 \%$ mortality). Single injections of LPS in FCA also produced high agglutination titers (2048), but protection was less than that obtained with multiple injections in FCA (20 vs $3.3 \%$ mortality). Multiple injections of whole cells in FCA produced high titers (2730) and strong protection $(8.3 \%$ mortality). Single injections of the whole cells also yielded respectable titers (1220) and some protection $(31.1 \%)$. Multiple and single injections of the bacterin in saline resulted in modest antibody levels and no protection. Injected FCA alone, and vaccination by immersion (single and multiple dips, with and without hyperosmotic pretreatment) yielded no protection. These results indicate that E. ictaluri LPS preparations are capable of enhancing immunity against E. ictaluri, but practical methods for administering the vaccine must still be found.
\end{abstract}

\section{INTRODUCTION}

Studies on the immune response of fish have employed many antigens including particulate (virus), cellular (bacteria) and molecular (proteins, carbohydrates, and haptens) substances. In a few cases, lipopolysaccharides (LPS) or endotoxins from the bacterial cell wall have been used to stimulate an immune response in fish (Cisar \& Fryer 1974, Paterson \& Fryer 1974, Busch 1978, Ingram \& Alexander 1980). Enteric septicemia of catfish (ESC), caused by Edwardsiella ictaluri (Hawke 1979, Hawke et al. 1981) is the most important bacterial disease of cultured channel catfish (Beleau \& Francis-Floyd 1986). Interest in developing an anti-E. ictaluri vaccine has increased because of the severity of the disease. The objective of this study was to determine whether $E$. ictaluri LPS is immunogenic in channel catfish Ictalurus punctatus and to compare

\footnotetext{
-Present address: Faculty of Marine Science, King Abdulaziz University, Jeddah, Saudi Arabia

- Addressee for reprint requests

the immunogenicity of the LPS with that of the whole cell antigen.

\section{MATERIALS AND METHODS}

Edwardsiella ictaluri (Hawke et al. 1981) (ATCC 33202) was reconstituted from lyophilized pellets and grown on brain-heart infusion (BHI) agar plates at $30^{\circ} \mathrm{C}$. Cells were removed from the plates and suspended in either $0.85 \%$ saline or phosphate-buffered saline (PBS, pH 7.2).

One-year-old channel catfish (averaging $60 \mathrm{~g}$ each and $20 \mathrm{~cm}$ total length) were acclimated in the laboratory for 2 wk prior to experimentation. All experiments were carried out in $100 \mathrm{l}$ fiberglass tanks with a continuous water flow of $31 \mathrm{~min}^{-1}$ at a temperature between 25 and $27^{\circ} \mathrm{C}$ and with supplemental aeration.

Lipopolysaccharide vaccine studies. The Edwardsiella ictaluri lipopolysaccharide, characterized by Saeed (1983), was extracted from whole cells using the hot aqueous phenol procedure of Westphal \& Jann 
(1965). The LPS was treated with deoxyribonuclease and ribonuclease (Sigma Chemical Co., St. Louis, Missouri, USA) as described by Stevens et al. (1980).

Preliminary studies indicated that $0.2 \mathrm{mg}$ (dry weight) of LPS per fish was the optimum immunizing dose. In triplicate groups, 20 fish each were immunized by intraperitoneal (IP) injection with LPS in either Freund's complete adjuvant (FCA) or in saline. A control group of 20 fish was injected with saline only. Each fish was injected with $0.2 \mathrm{ml}$ of a mixture comprised of equal volumes of LPS in saline and FCA and containing $0.2 \mathrm{mg}$ (dry weight) of LPS. Ten d later, the fish were injected with the same LPS dose in Freund's incomplete adjuvant. On Day 17 , each fish was given a final injection of LPS in saline. Control fish, immunized with LPS in saline or with saline only, were injected using the same schedule. Fifteen fish from the control and treatment groups were bled for agglutination antibody titration on Day 21 and returned to their respective tanks.

The immune response of channel catfish to a single injection of LPS in FCA or in saline was also determined using 20 fish per antigen preparation. Twenty saline-injected fish served as controls. Ten fish from each treatment were bled for agglutination antibody titration $21 \mathrm{~d}$ following vaccination and returned to their respective tanks.

To determine if FCA alone produced immunity to Edwardsiella ictaluri, each of 16 channel catfish was injected IP with $0.2 \mathrm{ml}$ of a 1:1 FCA-saline mixture and held at $20^{\circ} \mathrm{C}$ for $21 \mathrm{~d}$. The fish were then challenged with $E$. ictaluri. Non-adjuvant injected control fish were also maintained and challenged.

Whole cell vaccine. Edwardsiella ictaluri, suspended in PBS, was exposed to $1 \%$ formalin for $6 \mathrm{~h}$ at $23^{\circ} \mathrm{C}$, washed in sterile PBS, and stored overnight at $4{ }^{\circ} \mathrm{C}$ in $0.1 \%$ formalin. To test for sterility, one ml of the suspension was inoculated into fluid thioglycolate medium and streaked on BHI plates and the media incubated for $72 \mathrm{~h}$ at $30^{\circ} \mathrm{C}$. The formalin-killed bacteria were finally washed with distilled water, lyophilized, and stored at $4{ }^{\circ} \mathrm{C}$ until used.

Formalin-killed cells were used to vaccinate fish using 4 different treatments and 3 replicates per treatment. Twenty fish per treatment per tank as well as 20 non-vaccinated control fish per tank were used. Fish were injected with $0.2 \mathrm{mg}$ of bacteria (dry weight) in FCA or in saline, or dipped in a suspension containing $0.2 \mathrm{mg}$ lyophilized cells $\mathrm{ml}^{-1}$ of water for $2 \mathrm{~min}$, or first dipped into a $2 \%$ saline solution for $1 \mathrm{~min}$ and then dipped in the vaccine as just described. For all treatments, immunization schedule, number of fish bled, determination of antibody titers, and challenge method were as described for fish immunized with LPS. Statistical comparisons between multiple treat- ments and single treatments were made by contrasting t-tests (SAS User's Guide 1979).

Agglutinating antibody detection. Blood was drawn from the caudal blood vessel into anticoagulant-free vacutainer tubes and allowed to clot at room temperature for $1 \mathrm{~h}$ and then at $4{ }^{\circ} \mathrm{C}$ overnight. The serum was removed and heat-inactivated at $56^{\circ} \mathrm{C}$ for $30 \mathrm{~min}$. Doubling dilutions of the sera were prepared in standard, round-bottom 96-well microtiter plates using $0.85 \% \mathrm{NaCl}$ as the diluent. Formalin-killed Edwardsiella ictaluri at a concentration of $0.2 \mathrm{mg} \mathrm{m}^{-1}$ (dry weight) was used as the antigen. Equal volumes of serum and antigen $(0.05 \mathrm{ml})$ were incubated at $23^{\circ} \mathrm{C}$ for $24 \mathrm{~h}$ and the agglutination titers determined. Controls consisted of wells containing saline and antigen and or non-immune serum and antigen.

Test for protective immunity. A lethal dose $80 \%$ endpoint $\left(\mathrm{LD}_{80}\right)$ was calculated for the virulent strain of Edwardsiella ictaluri. Five different concentrations of bacteria from $1 \mathrm{mg}$ (lyophilized) to $0.158 \mathrm{mg}$ were injected IP into groups of 10 channel catfish held at $23^{\circ} \mathrm{C}$. Mortality data were plotted on a probit scale and analyzed statistically by the method of Litchfield \& Wilcoxon (1949). The $5 \mathrm{~d} \mathrm{LD}_{80}$ of $1.25 \mathrm{mg}\left(5 \times 10^{9}\right.$ cells $)$ was determined by extrapolation from the probit plot and used to challenge the variously treated fish.

All immunized fish and the control fish were challenged with an $\mathrm{LD}_{80}$ of the virulent Edwardsiella ictaluri in $0.1 \mathrm{ml}$ given IP in saline $(0.85 \% \mathrm{NaCl})$. Fish were observed for $5 \mathrm{~d}$ during which time recently dead fish were removed and examined bacteriologically for E. ictaluri. Agglutination titers and mortalities obtained with fish receiving the various vaccination regimes were evaluated using contrasting t-tests (SAS User's Guide 1979).

To test the protective capability of FCA alone, each of 4 adjuvant-injected fish were injected IP with $0.1 \mathrm{ml}$ of serial 10 -fold dilutions $\left(10^{\circ}\right.$ through $\left.10^{-3}\right)$ of an Edwardsiella ictaluri culture containing $2.27 \times 10^{7}$ cells per $0.1 \mathrm{ml}$ in the $10^{\circ}$ dilution. Fish not injected with adjuvant were similarly challenged, and all fish were held in separate $40 \mathrm{l}$ aquaria at $20^{\circ} \mathrm{C}$ for $11 \mathrm{~d}$. Dead and moribund fish were examined for E. ictaluri by culture and by the indirect fluorescent antibody (FA) method.

\section{RESULTS}

Table 1 shows the antibody production and survival that resulted when fish were vaccinated with Edwardsiella ictaluri LPS by various methods and then challenged with viable $E$. ictaluri. Multiple injection with LPS in adjuvant produced significantly higher mean agglutinating antibody titers $(1: 1391)$ than injection with LPS in saline $(1: 136)$ or with saline 
Table 1. Ictalurus punctatus. Antibody response and survival in $60 \mathrm{~g}$ channel catfish vaccinated with $0.2 \mathrm{mg}$ of Edwardsiella ictaluri LPS and challenged with an $\mathrm{LD}_{80}$ of a virulent strain of $E$. ictaluri

\begin{tabular}{|c|c|c|c|c|c|}
\hline \multirow[b]{2}{*}{ Treatment } & \multirow[b]{2}{*}{ No. of injections } & \multicolumn{2}{|c|}{ Agglutination titers } & \multicolumn{2}{|c|}{ Challenge } \\
\hline & & No. of fish & Mean ${ }^{1,2}$ & No. challenged & $\%$ Dead $^{2}$ \\
\hline LPS + adjuvant & Mulitple & 15 & $\begin{array}{c}1391^{\mathrm{d}} \\
(256-2048)\end{array}$ & 60 & $3.3^{\mathrm{d}}$ \\
\hline LPS & Multiple & 15 & $\begin{array}{c}136^{\mathrm{b}} \\
(32-512)\end{array}$ & 60 & $36.7^{\mathrm{b}}$ \\
\hline Saline & Multiple & 15 & $\begin{array}{c}4^{c} \\
(1-16)\end{array}$ & 60 & $70.0^{c}$ \\
\hline LPS + adjuvant & Single & 10 & $\begin{array}{c}2048^{\mathrm{a}} \\
(2048-2048)\end{array}$ & 20 & $20^{\mathrm{d}}$ \\
\hline LPS & Single & 10 & $\begin{array}{c}77^{b} \\
(8-256)\end{array}$ & 20 & $80^{c}$ \\
\hline Saline & Single & 10 & $\begin{array}{c}5^{c} \\
(1-16)\end{array}$ & 20 & $80^{c}$ \\
\hline
\end{tabular}

alone $(1: 4)$. A single injection of E. ictaluri LPS in adjuvant also produced high titers $(1: 2048)$ but these were not significantly different from those resulting from multiple injections with LPS-adjuvant $(p>0.1)$.

LPS from Edwardsiella ictalun also provided significant $(p<0.01)$ protection against $E$. ictaluri when given in multiple doses with adjuvant. The mortality in different groups of fish vaccinated with LPS in FCA, LPS in saline, and saline was 3.3, 36.7, and $70 \%$, respectively. A single injection of LPS in FCA provided protection ( $20 \%$ mortality), but the protection was not as strong as that resulting from multiple injections. The other 2 groups of fish receiving single injections of LPS in saline or saline alone suffered $80 \%$ mortality. In the brief experiment in which the immunogenicity of FCA alone was examined, no protection was provided to channel catfish challenged with E. ictaluri (Table 2). E. ictaluri was isolated from kidneys of dead fish in this

Table 2. Ictalurus punctatus. Effects of Freund's Complete Adjuvant on resistance of channel catfish to Edwardsiella ictaluri

\begin{tabular}{|ccc|}
\hline $\begin{array}{c}\text { Injection } \\
\text { dose }\end{array}$ & $\begin{array}{c}\text { \% Mortality } \\
\text { Adjuvant } \\
\text { injected }\end{array}$ & $\begin{array}{c}\text { No adjuvant } \\
\text { injected }\end{array}$ \\
\hline $2.27 \times 10^{7}$ & 100 & 100 \\
$2.27 \times 10^{6}$ & 100 & 100 \\
$2.27 \times 10^{5}$ & 100 & 100 \\
$2.27 \times 10^{4}$ & 100 & 0 \\
Four fish in each regime were injected with $0.1 \mathrm{ml}$ of \\
bacterial suspension
\end{tabular}

experimental group and it was also identified in FAstained smears of their kidneys.

Multiple vaccination with injected whole cell Edwardsiella ictaluri bacterin in adjuvant produced high mean antibody titers $(1: 2730)$ and excellent protective immunity ( $8.3 \%$ mortality) (Table 3 ). Multiple vaccinations by injection of the bacterin in saline elicited increased mean agglutinating antibody titers $(1: 314)$ but produced no protection (mortality was $76.7 \%$ ). The control group had a mean antibody titer of $1: 6$ and mortality of $75 \%$ after challenge.

Vaccination by single injection with the whole cell bacterin in adjuvant or in saline produced elevated antibody titers (Table 3). However, only the former vaccination method resulted in any protection.

Vaccination by immersion with or without a preliminary hyperosmotic dip elicited relatively low agglutinating antibody titers. However, dip-vaccinated fish were not protected from challenge even when multiple dips were administered (Table 3).

\section{DISCUSSION}

It is clear that Eduardsiella ictaluri LPS can result in a protective immunity in channel catfish against the pathogen. In the present study, $0.2 \mathrm{mg}$ of LPS elicited a strong antibody response and provided protective immunity when the antigen was given with FCA in single or in multiple injections. An E. ictaluri LPS dose of $0.2 \mathrm{mg}$ was chosen over the $1 \mathrm{mg}$ dose to immunize channel catfish because in preliminary studies (unpubl.) the $0.2 \mathrm{mg}$ gave a significantly higher antibody titers $(p<0.01)$. Multiple injections of LPS were 
Table 3. Ictalurus punctatus. Antibody response and survival in $60 \mathrm{~g}$ channel catfish vaccinated with $0.2 \mathrm{mg}$ of Edwardsiella ictaluri bacterin and challenged with an $\mathrm{LD}_{80}$ of a virulent strain of $E$. ictaluri

\begin{tabular}{|c|c|c|c|c|c|c|c|c|}
\hline \multirow{3}{*}{ Treatment } & \multicolumn{4}{|c|}{ Multiple vaccination } & \multicolumn{4}{|c|}{ Single vaccination } \\
\hline & \multicolumn{2}{|c|}{ Agglutination titers ${ }^{1}$} & \multicolumn{2}{|c|}{ Challenge } & \multicolumn{2}{|c|}{ Agglutination titers ${ }^{1}$} & \multicolumn{2}{|c|}{ Challenge } \\
\hline & $\begin{array}{l}\text { No. } \\
\text { of fish }\end{array}$ & Mean ${ }^{2}$ & $\begin{array}{c}\text { No. } \\
\text { challenged }\end{array}$ & $\%$ Dead $^{2}$ & $\begin{array}{l}\text { No. } \\
\text { of fish }\end{array}$ & Mean $^{2}$ & $\begin{array}{l}\text { No. } \\
\text { of fish }\end{array}$ & $\%$ Mortality $^{2}$ \\
\hline $\begin{array}{l}\text { Bacterin in } \\
\text { adjuvant }\end{array}$ & 15 & $\begin{array}{c}2730^{\circ} \\
(2048-4096)\end{array}$ & 60 & $8.3^{\mathrm{a}}$ & 15 & $\begin{array}{c}1220^{d} \\
(128-4096)\end{array}$ & 55 & $31.1^{\circ}$ \\
\hline $\begin{array}{l}\text { Bacterin in } \\
\text { saline }\end{array}$ & 15 & $\begin{array}{c}341^{b} \\
(256-512)\end{array}$ & 60 & $76.7^{b}$ & 15 & $\begin{array}{c}158^{\mathrm{b}} \\
(32-512)\end{array}$ & 20 & $73.3^{\mathrm{b}}$ \\
\hline Dip in bacterin & 15 & $\begin{array}{c}171^{\mathrm{b}} \\
(64-512)\end{array}$ & 60 & $81.7^{b}$ & 15 & $\begin{array}{c}248^{\mathrm{b}} \\
(64-1024)\end{array}$ & 58 & $65.5^{\mathrm{b}}$ \\
\hline $\begin{array}{l}\text { Pre-hyperosmo- } \\
\text { tic dip }\end{array}$ & 15 & $\begin{array}{c}158^{\mathrm{b}} \\
(64-256)\end{array}$ & 60 & $78.3^{\mathrm{b}}$ & 15 & $\begin{array}{c}222^{b} \\
(32-1024)\end{array}$ & 58 & $67.0^{\mathrm{b}}$ \\
\hline Saline injection & 15 & $\begin{array}{l}6^{c} \\
(1-16)\end{array}$ & 60 & $75^{\mathrm{b}}$ & 15 & $\begin{array}{c}99^{c} \\
(32-356)\end{array}$ & 60 & $66.7^{b}$ \\
\hline
\end{tabular}

more immunogenic than single injections and best protection occurred when the vaccine contained FCA. Although vaccination using a single injection of LPS in FCA is a feasible method for vaccinating relatively small numbers of fish, it would not be practical on a production basis. Vaccination using multiple injections would be an impossible task on a production basis.

Like LPS vaccines, whole cell vaccines resulted in elevated antibody titers and protection against Edwardsiella ictaluri when administered with FCA. However, in the absence of FCA, whole cell vaccines proved less protective than LPS vaccines: they resulted in protection only when administered in multiple doses.

Olivier et al. (1985) reported that FCA provided protection against several microbial fish pathogens in coho salmon Oncorhynchus kisutch. However, channel catfish injected with FCA alone showed no enhanced resistance to Edwardsiella ictaluri.

In the present study the whole cell bacterin administered by injection was superior to vaccination by dipping in terms of antibody response and protection. However, in view of the fact that dip-administered vaccines have proved effective against certain bacterial diseases of salmonids, the possibility of developing a dip-administered Edwardsiella ictaluri vaccine is being actively investigated.

Acknowledgements. Research was supported by U.S.D.A. Regional Cooperative Research, Freshwater Food Animals (S-168) and the Southeastern Cooperative Fish Disease Project.

\section{LITERATURE CITED}

Beleau, M. H., Francis-Floyd, R. (1986). Clinical management of enteric septicemia of catfish (ESC). Miss. Vet. J. Suramer. p. $14-15$

Busch, R. A. (1978). Enteric red mouth disease (Hagerman strain). Mar. Fish Rev. 40: 42-51

Cisar, J. O., Fryer, J. L. (1974). Characterization of antiAeromonas salmonicida antibodies from coho salmon. Infect. Immun. 9: 236-243

Hawke, J. P. (1979). A bacterium associated with disease of pond cultured channel catfish, Ictalurus punctatus. J. Fish. Res. Bd Can. 36: 1508-1512

Hawke, J. P., McWhorter, A. C., Stegerwalt, A. G., Brenner, D. J. (1981). Edwardsiella ictaluri sp. nov., the causative agent of enteric septicemia of catfish. Int. J. Syst. Bacteriol. 31: 396-400

Ingram, G. A., Alexander, J. B. (1980). The irnmune response of the brown trout (Salmo trutta) to lipopolysaccharide. J. Fish Biol. 16: 181-197

Litchfield, J. T., Wilcoxon, F. (1949). A simplified method of evaluating dose-effect experiments. J. Pharmac. exp. Ther. 96: 99-113

Olivier, G., Evelyn, T. P. T., Lallier, R. (1985). Immunity to Aeromonas salmonicida in coho salmon (Oncorhynchus kisutch) induced by modified Freund's complete adjuvant: its non-specific nature and the probable role of macrophages in the phenomenon. Dev. comp. Immun. 9: $419-432$

Paterson, W. D., Fryer, J. L. (1974). Immune response of coho salmon (Oncorhynchus kisutch) to Aeromonas salmonicida cells administered intraperitoneally in Freund's complete adjuvant. J. Fish. Res. Bd Can. 31 (11): $1751-1755$

Saeed, M. O. (1983). Chemical characterization of the lipopolysaccharide of Edwardsiella ictaluri and the immune response of channel catfish to this fraction and to whole cell antigen with histopathological comparisons. Ph. D. dissertation, Auburn University, Alabama 
SAS Users Guide (1979). SAS Institute, Inc., Cary, North Carolina

Stevens, R. H., Sela, M. N., McArthur, W. P., Novotny, A., Hammond, B. F. (1980). Biological and chemical characterization of endotoxin from Capnocytophaga sputigena. Infect. and Immun. 27 (1): 53-54
Westphal, O., Jann, K. (1965). Bacterial lipopolysaccharide extraction with phenol-water and further applications of the procedure. In: Whistler, R. L., Wolform, M. L. (ed.) Methods in carbohydrate chemistry, Vol. V. Academic Press, New York, p. 83-91

Responsible Subject Editor: Dr. T. Evelyn; accepted for printing on November 26, 1986 